\title{
Developing A Personal Financial Planning Program: More Than Just Courses
}

\author{
Charles L. Martin Jr., (E-mail: Chuck819@comcast.net), Towson University
}

\begin{abstract}
Personal financial planning is considered one of the major growth professions of the coming decade. Besides providing an opportunity for employment, a major in personal financial planning can open the door to a rewarding and challenging career. Career opportunities in the personal financial planning field include opening a private practice or being employed by a financial institution, credit union, insurance company, accounting firm or a financial services company. In addition, planners may work in employee benefits or pension departments of large corporations or for public institutions such as universities or state and federal government agencies. In order to develop a successful personal financial planning program, one must consider more than just the courses to be offered. A successful program also requires: Gaining Program Support, Attracting Students, Pivotal First Course, Professional Community Involvement, and Continuous Assessment. It is the objective of this manuscript to set forth an action plan that may serve as a model for the development of a successful financial planning program.
\end{abstract}

\section{INTRODUCTION}

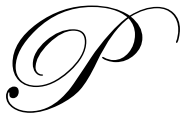

ersonal financial planning is considered one of the major growth professions of the coming decade. According to the Jobs Related Almanac (Fifth Edition), financial planners rank the highest of 250 jobs surveyed. Based upon cumulative scores earned in six equally weighted core job factors: Environment, Income, Outlook, Physical Demands, Security and Stress; the Almanac cited financial planning as the "nation's best job" in terms of high compensation, lots of autonomy and tremendous demand for one's skills.

As the population becomes better educated and wealthier, consumers feel more anxious and more in need of professional advice. With the myriad of new retirees, aging Baby Boomers, and young corporate executives and entrepreneurs demanding expert financial guidance, the opportunities for financial planners will increase markedly today and in the future. The explosion of financial planning and investment information online has only exacerbated the need for financial advisors to help sort it out. As awareness of this occupation grows so will the opportunities.

Presently, one-fourth of personal financial advisors are self-employed operating small investment advisory firms, usually located in urban areas. The majority of salaried advisors-nearly 6 out of 10-work for security and commodity brokers, exchanges, and investment services firms. About 1 in 7 personal financial advisors work for commercial banks, savings institutions, and credit unions. A small number work for insurance carriers and insurance agents, brokers and services.

Planners may move from individual clients to working with financial counseling programs for banks, government or private agencies, working in health care industries, or directing finances for nonprofit organizations or corporations. However, those financial planners who advise individuals take a lifelong, comprehensive view of financial planning. As such, they analyze and provide advice on all aspects of an individual's financial picture, including personal income tax, employee benefits, retirement planning, estate planning, alternative investment strategies, and insurance needs. Strong interpersonal skills and sales ability are crucial to success as is good communication skills because these professionals must present complex financial concepts and strategies in easy-tounderstand language to their clients. 
Certification, although not required for personal financial advisors, can enhance professional standing and is strongly recommended by many financial companies. The Chartered Financial Consultant (ChFC) designation, issued by the American College in Bryn Mawr, Pennsylvania, requires experience and completion of an eight-course study program. While the Certified Financial Planner (CFP) designation issued by the CFP Board of Standards, requires relevant experience, completion of education requirements, passage of a comprehensive examination, and adherence to an enforceable code of ethics.

Formal licensure is not a requirement to work as a personal financial advisor. However, advisors who sell stocks \& bonds (SEC's Series 7 license), mutual funds (SEC's Series 6 license), insurance or real estate, do need appropriate licensure.

The body designated to award the title "Certified Financial Planner" (CFP) is the Institute of Certified Financial Planners located in Denver, Colorado. In 2003, The Academy of Financial Services (AFS) and Certified Financial Planner Board of Standards Inc. ${ }^{\text {ii }}$ (CFP Board) organizations entered into a formal collaboration to design and disseminate the AFS and CFP Board Model Financial Planning Curriculum. The two organizations determined that the academic community would benefit from a coordinated curriculum for students pursuing career studies in the relatively new field of personal financial planning. The goals of the AFS and CFP Board Model Financial Planning Curriculum Project were:

- $\quad$ to develop a high-quality curriculum appropriate for bachelor's and master's degrees in financial planning (also appropriate for non-degree certificate programs), which captures the best thinking of academics in the field, as well as meeting content, level and length requirements for CFP Board-Registered Programs, ${ }^{\text {iii }}$

- $\quad$ to have a major positive impact on the quality, consistency and spread of university-level financial planning education.

Presently, numerous institutions of higher learning are registered with the Institute of Certified Financial Planners in order to offer financial planning classroom programs utilizing the following seven Model Curriculum courses:

\section{Personal Financial Planning}

Financial planning process, client interactions, time value of money applications, personal financial statements, cash flow and debt management, asset acquisition, education planning, overview of risk management investment planning and retirement planning, special circumstances, plan integration, ethics, and the business of financial planning.

\section{Insurance Planning}

This course introduces students to risk management and insurance decisions in personal financial planning. Topics include insurance for life, health, disability, property and liability risks, as well as annuities, group insurance, and long term care.

\section{Investment Planning}

This course provides the student with an understanding of the various types of securities traded in financial markets, investment theory and practice, portfolio construction and management, and investment strategies and tactics.

\section{Income Tax Planning}

The course focuses on principles and current law and practice of income taxation and its impact on financial planning for individuals, couples and families in their roles as investors, employees, and business owners. 


\title{
Retirement Planning
}

The intent of the retirement planning course is to provide individuals with knowledge of both public and private retirement plans. The public plans include Social Security, Medicare, and Medicaid. The private plans include defined benefit and defined contribution plans and their regulatory provisions. The specifics of the various plans are analyzed as well as non-qualified deferred compensation plans. Finally, issues that individuals face in retirement, such as life-styles choices and medical issues are discussed.

\section{Estate Planning}

The course in estate planning focuses on the efficient conservation and transfer of wealth, consistent with the client's goals. It is a study of the legal, tax, financial, and non-financial aspects of this process, covering topics such as trusts, wills, probate, advanced directives, charitable giving, wealth transfers and related taxes.

\section{Personal Financial Planning Capstone}

This course will engage the student in critical thinking and decision-making about personal financial management topics in the context of the financial planning process.

The Capstone course will be taken as the last course in the financial planning curriculum or concurrently with other courses in the final term of study. Required skills include competency with financial calculators and with spreadsheet, presentation, and word processing software.

\author{
- $\quad$ Principles of Personal Financial Planning - pre-requisite \\ - $\quad$ Insurance Planning - pre-requisite \\ - $\quad$ Income Tax Planning-pre-requisite \\ - Investment Planning - pre-requisite \\ - $\quad$ Retirement Planning - pre-requisite or co-requisite \\ - $\quad$ Estate Planning — pre-requisite or co-requisite (Institute of Certified Financial Planners)
}

Establishing the curriculum by utilizing this Model Program is the easy part of developing a university level PFP program. The far more difficult task is to gain administrative, departmental, faculty and practitioner support for the program. Once that support has been gained, student interest must then be garnered.

\section{NEED TO GAIN PROGRAM SUPPORT}

With limited resources, budgetary constraints and turf battles, it is not easy to obtain acceptance of a new program. The university administration will want to know the estimated number of students that will be attracted into the program while also questioning the ability to serve those students with present, as opposed to increasing, resources. Departments within the university will be concerned as to how this program will influence enrollment within established programs. Of particular departmental concern will be the potential loss of students.

The department taking the lead in promoting the PFP program will be responsible for marketing the program to the administration and to other departments. The ability to attract students and hence tuition will be of concern. Professionals within the PFP arena have varied backgrounds; therefore, all students, regardless of their major, may be interested in PFP. Administrators would be very interested if students majoring in one discipline, such as liberal arts, may generate extra revenues by taking additional credits enrolling in PFP courses. Other departments would also welcome this point since those departments would not be losing majors.

Cost is another consideration. Assuming there is adequate classroom facilities to accommodate more classes, the most pressing consideration is additional instructional costs. Based on the seven-course PFP curriculum model identified earlier, two of the courses, Investments and Taxes, are probably presently offered and staffed. The other five courses would require additional faculty. Of the five, at least three courses, Insurance, Retirement 
Planning, and Estate Planning could be easily staffed by practitioners who may be hired as adjunct faculty at a lower cost than full time faculty. The last two courses representing the first course in the curriculum, Personal Financial Planning, and the last course in the curriculum, Personal Financial Planning Capstone, may or may not be staffed by adjunct faculty. This staffing decision may have as much to do with other intangibles, such as attracting students into the program, consistency of instruction, and external accreditation as it does with managing costs.

\section{ATTRACTING STUDENTS}

It is very difficult to attract students into a program if they know very little about the discipline. It is also very difficult to attract students into the program without initial exposure to the discipline. If the first course in the program, Personal Financial Planning,_is but an elective course, not many students will enroll and hence the PFP program will be marginal, at best. It is critical that one or more disciplines require this first PFP course. Other than the department which is offering the PFP program, requiring the first program course is not an easy sell to other departments assuming there is little room in the curriculum for another required course or if a required course must be dropped in order to add this one.

Other departments must be convinced of the importance of requiring the Personal Financial Planning course. The most compelling argument for making this course a requirement is the information covered in this course is not covered elsewhere in the curriculum and that the information is a necessity for all professionals. Some topics covered in this first course, but not covered in other courses, follow:

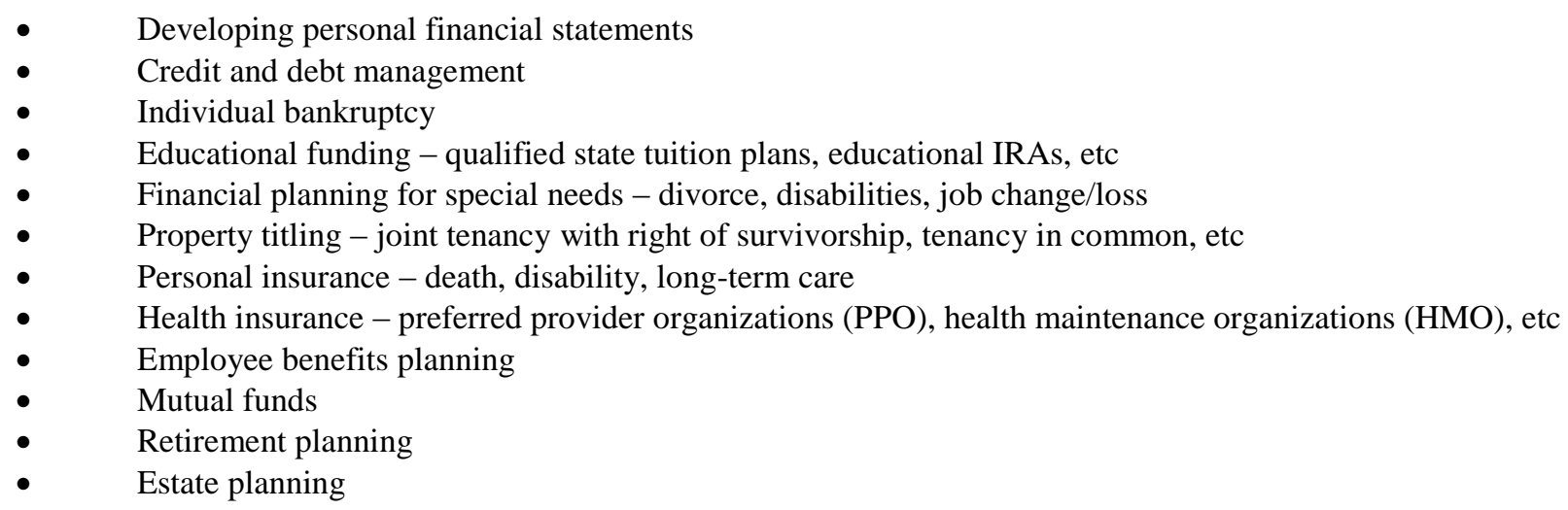

Should the Personal Financial Planning course be offered as a lower level or upper level course? Some feel this course should be offered at the upper level after students have taken basic business courses, especially accounting. If such pre-requisites exist, then non-business students would be less likely to take the course. This limits the potential interest and ensuing enrollment in the PFP program. However, if the Personal Financial Planning course is offered at the lower level with no pre-requisites, the student population interested in taking this course increases significantly as would the potential enrollment in the PFP program. Unfortunately, offering any of the seven courses at lower academic levels would violate the Model Program as devised by the CFP and AFS.

\section{THE PIVOTAL FIRST COURSE}

As previously noted, the first course in the PFP program covers many topics that are not covered elsewhere in the academic curriculum and these topics are of personal and professional benefit to all who enroll. However, the delivery of these topics should not consist solely of the standard lecture format. Students should be engaged in the topics by the introduction of relevant outside assignments, case studies, and interaction with the professional community.

Simple, but very relevant, outside assignments may generate a greater interest in the course. Students, as well as many others, often have a difficult time with cash flow. Therefore, one assignment may require the preparation of a personal cash budget for the upcoming year. Additionally, there are significant differences among insurance companies as to charges for automobile insurance. To find that comparison-shopping has its benefits, 
students should investigate car insurance rates among three different companies. Another assignment may entail comparison of credit card rates, including promotional rates, terms, capped rates, financial protection and award programs.

Case studies often bring course material into focus. Once again relevance is of issue. Students should be assigned simplistic, but realistic, cases similar to what they may encounter within the first few years of graduation. Once such case may involve newlyweds living in an apartment with the aspiration of moving into a house within five years while also saving for retirement. Much more information would be provided in order for the students to develop a reasonable plan to accomplish the newlyweds' goals.

Personal financial planning is a very pragmatic endeavor. Bringing the real world into the classroom as well as introducing students into the real world should be a vital part of the Personal Financial Planning course. One way to bring the real world into the classroom is to have practitioners serve as guest lecturers. The topics of the guest lecturers should be of direct interest to the students. An insurance agent may present automobile, health and life insurance. A personal financial planner would address the importance and financial growth potential of setting aside funds for retirement at the earliest possible age. While a real estate agent along with a mortgage loan officer may form a panel to present what is involved in purchasing a house. Additionally, another way to bring students into the real world is to require each student to attend at least one local professional meeting. In this manner, students would be exposed to the professional responsibilities and concerns of financial planners in a dynamic, realistic setting.

\section{ENGAGE THE PROFESSIONAL COMMUNITY}

There should be greater interaction between the professional financial planning community and the academic community than guest lecturers and students attending professional meetings. The two communities should be intertwined and act as one in the implementation of the PFP program. The interaction should begin at the planning stage and continue throughout the program.

The academic unit should invite practitioners representing numerous companies and organizations as well as different fields with the discipline of financial planning to join a PFP Advisory Board. This board should be proactive, instrumental in policy-making, not just window dressing. Board members, either directly or indirectly through their representatives, should be involved in the PFP program. Classroom lecturers and professional meeting involvement have been previously addressed. Further involvement may entail annual banquets and internships.

Each year, an annual banquet may be held to recognize outstanding accomplishments by individual students and to honor one practitioner as the "PFP of the Year". Program activities may be recapped and future activities set out. A separate student PFP Association may be formed with students becoming more directly involved with the profession.

Members of the Advisory Board should be initial sponsors of student and faculty internships. Firms that do not have members on the board should also be contacted regarding internships. Whether the internships are for faculty or students, the experience should be meaningful.

Students, in particular, should not be employed as "gophers". The work may entail gathering background data on prospective clients, meeting with clients as an observer, completing detail documentation that accompanies financial contracts with clients, etc. The practitioner and student should also sign a statement as to what the job entailed. Students should not work gratis. Students should receive three credits as well as be paid a competitive wage. Additionally, it is hoped that the student internship would lead directly to a permanent position with the firm.

Faculties who teach in the PFP Program should be encouraged to become actively involved in the profession. One way to become involved is to serve a faculty internship. A faculty internship may be served during the summer or as a sabbatical. 


\section{CONTINUOUS ASSESSMENT}

For continuous improvement, there should be ongoing feedback regarding each course, instructor, guest lecturer, and program. Upon completion of each course, students should evaluate course, instructor, and guest lecturer quality. The evaluation should incorporate open-ended questions and should solicit recommendations for improvement. Instructors should also critically evaluate each course. Guest lecturers should also provide their input after presenting.

Whether a graduate secures a job or not, upon program completion, all graduates should be interviewed by the head of the program to discern what the graduate thought was beneficial and what was not beneficial within the program. Once out of the program and working for approximately one year, program graduates should be asked to list the pros and cons of the program and to make suggestions for improvement. The initial and subsequent feedback should be used to improve the PFP program.

${ }^{\mathbf{i}}$ AFS is an academic organization whose mission is:

The primary objectives and purposes of this organization shall be to:

- Encourage basic and applied research in the area of personal financial planning and financial services;

- Encourage the development of the curricula in the financial services field at the university level;

- Encourage interaction between financial services professionals and academicians.

Source: www.academyfinancial.org, March 5, 2004

${ }^{\text {ii } C F P ~ B o a r d ~ i s ~ a ~ p r o f e s s i o n a l ~ r e g u l a t o r y ~ o r g a n i z a t i o n ~ w h o s e ~ m i s s i o n ~ i s: ~}$

Certified Financial Planner Board of Standards Inc., a professional regulatory organization, fosters professional standards in personal financial planning so that the public values, has access to, and benefits from competent and ethical financial planning.

Source: www.CFP.net, March 5, 2004

CFP Board owns the certification marks CFP ${ }^{\circledR}$, Certified Financial Planner ${ }^{\mathrm{TM}}$, and CFP (with flame logo) ${ }^{\circledR}$, which it grants to individuals who meet its initial and continuing certification requirements. Its certification requirements include education, examination, experience, and ethics.

iii CFP Board's requirements for registration of a financial planning curriculum include, without limitation, the requirement that the curricula be at the upper division baccalaureate level or higher, be at least 15 semester credit hours in length (using traditional measures for granting credit hours), and cover the topics on CFP Board's current topic list, which is derived from its periodic job analysis study of $\mathrm{CFP}^{\circledR}$ practitioners. 